\title{
Spain, a via media of welfare development
}

\author{
Luis Moreno
}

\author{
Unidad de Políticas Comparadas (CSIC)
}

\section{Introduction}

The Spanish welfare state incorporates elements of both Bismarckian and Beveridgean traditions, and can be labelled as a via media with respect to other regimes of social protection. It combines universal and targeted access to services and benefits. The most relevant factor conditioning welfare development in Spain is the importance of decentralisation both at the level of planning and policy implementation. Decentralisation of social services has had much greater impact than privatisation.

After a long hyper-centralist dictatorship (1939-75), a peaceful transition to democracy (1975-79), and an active involvement in the process of Europeanisation after its accession to the EEC (1986), Spain has undergone deep and far-reaching social transformations. In economic terms, Spanish development has been outstanding: in 1959 the Spanish GDP per head was 58.3 per cent of the EU average; in 1985, 70.6 per cent and, by 1998, 81.5 per cent. Spain would match the EU mean by the year 2025 if the annual 'catching-up' rate of 0.8 per cent were maintained. No other country in the group of the advanced industrial democracies has achieved a comparable rate of economic growth. However, economic problems, high levels of unemployment, a severe demographic imbalance and the abrupt decline of the traditional system of domestic care are now threatening the stability of the welfare settlement.

This working paper analyses developments in social policy and welfare in Spain during the second half of the 20th century and examines current reforms and policy changes for the near future. In particular, it focuses on the process of devolution of powers to the regions (Comunidades Autónomas). It also examines changes in the areas of unemployment, pensions and the financing of social policies, which are regarded as having particular relevance to Spain's welfare future. The development of the Spanish welfare system is a story of relatively successful expansion. It shows how sub-national government can play a leading role in welfare innovation.

\section{Political and social actors}

The development of welfare in Spain can only be understood in the context of the historical background prior to the transition from Francoism to democracy (1975-78). The peaceful reformist democratic transition was made possible by the deployment of consensual politics among representatives, parties and social actors, who accepted the fact that the reformprocess had to take into account the previous institutional framework. Thus, the consolidation of Spain's welfare state had to evolve from the institutions and social protection policies developed during Franco's dictatorship (1939-75).

\section{The legacy of Francoism}

After the Spanish Civil War (1936-1939), the Francoist regime brought together a 
heterogeneous alliance of conservative and fascist groups, whose paramount concern was law and order. Their legitimacy was founded on the support of both the Army and the Catholic Church. This loose coalition enjoyed a certain degree of autonomy, in comparison to the type of state that developed in France, Germany, and Italy after World War II. The social losers of the Spanish Civil War were mainly the working class, the peasantry in the south of Spain, the republican and liberal middle-class factions, and some important political and cultural groups in Madrid as well as among the peripheral nationalities (mainly Catalonia, the Basque Country, and Galicia).

Francoism was above all representative of a reactionary despotism which aimed to accelerate and guarantee a rapid process of capitalist accumulation. In order to achieve this goal Francoism deployed political repression and violence in a selective manner (Flaquer, Giner and Moreno, 1990). The long duration of Franco's regime allowed for the slow coalescence of the several ruling classes of Spain. This coalescing ruling class was essentially a 'distributional coalition', engaging in rent-seeking rather than in the general well-being of society and in the increase of collective welfare and prosperity. Having said that, Francoism manufactured a demagogic façade concerned with the social well-being of Spaniards: the so-called obras sociales (social works).

In general terms, social policy in Spain under Francoism can be divided into three periods:

From 1940 until the late 1950s. This period was characterised by an attempt to achieve total autarchy with no foreign interference. Social policy was largely neglected and oriented towards both charity and beneficence.

"Our State must be Catholic in the social", declared Franco in 1937. The obra social was set up in order to "bring joy and bread to the Spanish families". The worker was regarded as a unit of economic production and, accordingly, was entitled to receive social protection against unexpected risks. In turn, he or she should be obedient and diligent. This kind of Catholic paternalism had been elaborated by the most reactionary sector of Spanish Catholicism, which advocated that income should correspond to social status.

A peculiar aspect incorporated in the Fuero del Trabajo, a constitutional Labour Act implemented by Franco's Government in 1938, concerned the social status of women. The Francoist State pursued the 'return' of women from the factory to the household. To this end a family subsidy was introduced within social security to encourage women to remain at home "taking care of their husband and children".

In 1939 the SOVI (Seguro Obligatorio de Vejez e Invalidez, Compulsory Insurance for Retirement and Invalidity) was introduced to provide benefits for low-waged employees. Public insurance was initially combined with a voluntary system of mutual benefit societies, which collapsed. In 1942, statutory sickness insurance was implemented. Its duration was limited in time regardless of the health condition of the claimant, and its implicit aim was to 'encourage' the employee to go back to work as soon as possible. Health services were delivered by both public and private institutions in agreement with the social security system. This latter arrangement secured the incomes of medical doctors, who in most cases also worked in the private sector. The pharmaceutical industry profited abundantly as well. In turn, the quality of the public health service was very poor.

\section{The years from 1959 to 1967 corresponded to desarrollismo (economic}

'developmentalism'). The Stabilisation Plan of 1959 marked the turning point for the progressive liberalisation of the Spanish economy. Technocrats of the Opus Deiheld the key posts in Franco's government and imported models of 'indicative planning' from France. [1] Some steps were taken to implement a system of labour regulation that moderated somewhat its dirigiste nature. In 1958, for example, a Collective Agreements Act allowed employers and employees to negotiate wages (which had previously been regulated by the Ministry of Labour) at the factory level.

Catholics aimed to develop their own trade union movement, intended to support a 
dominant Christian Democratic party after the demise of General Franco. Paradoxically, during the 1960s, some youth organisations became radical Catholic institutions that collaborated with Marxist organisations opposed to the Franco regime. The Social Doctrine of the Roman Catholic Church was 're-interpreted' by radical Catholics according to more egalitarian principles. They advocated the disappearance of the huge disparities between classes. In fact, many of the early Catholic activists during the 1960 s took a leading role in the subsequent articulation of the Communist-controlled CCOO (Workers' Commissions). They also participated actively in the opposition to the Franco regime as members of clandestine left-wing parties.

In 1967 the Basic Law of social security (Ley de Bases de la Seguridad Socia) was put into effect. It had a universalistic vocation and went hand in hand with a timid fiscal reform. A peculiar model of economic development - vocationally neo-Keynesian but constrained by the rigidities of an authoritarian regime - attempted the transition from an agrarian society to a fully industrialised polity with some degree of success, modifying in this process the occupational structure of the country.

From the late 1960s until the transition to democracy (1975-1978) the opposition movement against Francoism became very active. These were the years of political and social turmoil that constituted the prelude to the transition to democracy after the death of Franco in November 1975. In 1969, don Juan Carlos had been appointed future head of state and, in 1970, a preferential treaty had been signed between Spain and the European Economic Community (EEC).

With the implementation of the General Education Law (Ley General de Educación) in 1970 and the General Law of social security Law (Ley General de la Seguridad Social) in 1974, the level of public spending rose very significantly. Considerable wage increases also took place between 1974 and 1976. These factors set the basis for the subsequent climate of social consensus that contributed to making the peaceful transition to democracy possible. The main bulk of social spending since the 1970 s was devoted to retirement pensions and unemployment benefits.

\section{Governmental policy in democratic Spain}

With the transition to democracy in Spain (1975-1979) a series of agreements among the main social and economic actors inaugurated a mode of democratic neo-corporatism as opposed to the non-democratic and despotic corporatism characteristic of Francoism. Early negotiations were geared at controlling inflation by means of wage restraint. In 1977, after the first democratic elections held in Spain since the II Republic (1931-39), the Pactos de la Moncloa were signed among all main Spanish political parties. These Pacts established a policy of mutual restraint between government, employers, and trade unions and were signed with the explicit intention of consolidating democracy. The avoidance of strikes and lockouts and the introduction of wage restraints were also accepted by all concerned in order to allay the fears of a military coup d'état [2]. The Moncloa Pacts, as well as the other social peace and wage restraint agreements that followed, were crucial for securing the consolidation of democracy in post-Franco Spain.

The first democratic Government of the post-Franco era established the General Directorate for Social Action and Social Services (Dirección General de Acción Social y Servicios Sociales) within the Ministry of Health and social security. This governmental body took over the responsibilities of social assistance and public charities, which had previously been attached to various departments of the central government (principally, the Home Ministry). It ran programmes such as those related to the Social Assistance Fund (Fondo de Asistencia Socia), whose non-contributory benefits covered old-age and disability pensions. This constituted the principal instrument of social assistance at that time. 
The contributory sector of the social security system provided services for employees and their dependants. In 1978, social security was re-structured with the grouping of old-age and disabled services into the Institute for Social Services (INSERSO-Instituto de Servicios Sociales), a quasi-autonomous public agency within the framework of the Ministry of Labour.

In parallel, local authorities (municipalities and provincial authorities) continued to run various programmes of social assistance, which were in many cases the inheritors of traditional public charities and beneficence. Private institutions also continued to provide charitable donations and some services, particularly those offered by Roman Catholic Church organisations. During the transition to democracy (1975-78), renewed demands for the implementation of new social services were coupled with an active mobilisation of social workers to develop a new framework of service provision (Sarasa, 1993; Casado et al, 1994).

Between 1980-82, the centre-right government of the UCD (Unión de Centro Democrático) initiated a process of economic rationalisation. This meant a moderation in wage increases, as well as the beginning of a process of re-structuring 'unproductive' industries. These policies were coupled with containment in the level of social spending (Rodríguez-Cabrero, 1989).

The Partido Socialista Obrero Español(PSOE) (Spanish Socialist Workers' Party) formed the government from 1982 to 1996. Policies carried out by the PSOE Governments were mainly aimed at the economic modernisation of Spain and the expansion of welfare. The 1982 electoral programme of the Spanish Socialists was phrased along 'orthodox' socialdemocratic lines. It advocated neo-Keynesian measures to strengthen internal demand by means of increasing public and social expenditure. However, the 'social liberals', whose policies diverged from the dogma of the traditional social-democratic left, took the initiative in economic policy-making. They recognised the shortcomings of the Socialist government in neighbouring France (see ch. 3), which had implemented demand-side policies unsuccessfully. They argued that large 'unproductive' industries had been kept alive artificially during late Francoism and should be 're-structured'.

The tough economic policy of adjustment carried out by the first Socialist Governments pumped resources into industrial re-structuring and liberalisation policies to the detriment of other public spending. Macro-economic reforms concerned large 'lame-duck' economic sectors (shipbuilding, iron or steel industries), and were implemented in an favourable international situation. This conjuncture allowed the government to carry out unpopular policies that would not jeopardise the political stability of the country.

1988 marks the beginning of a cycle of expansion of social spending and of major developments in social services. The Ministry of Social Affairs [3] was established, intended to develop social policies and public welfare intervention, which had been 'hidden' within the organisational structure of the Ministry of Labour. However, central intervention was conditioned by the consolidation of the regional systems promoted by the Spanish Comunidades Autónomas. Some argues against the establishment of a Ministry which would lack many powers already decentralised to mesogovernment (Beltrán, 1992).

The newly-created Ministry pursued co-ordination with the mesogovernments in the development of General Plans such as those concerning old age, drug addiction, equal opportunities, or young people. These plans did not pass into law, but were agreements intended to improve the working of systems of welfare provision throughout Spain. In particular, they paved the way for the future transfer of the social services of INSERSO to the regional level. The PSOE Government had previously failed in attempts to pass a National Social Services Act, designed to integrate all the social provisions of the contributory system of social security into one centrally-managed institutional framework, in 1983 and 1984. The Spanish regions were reluctant to lose their role as the main 
protagonists in the structuring of welfare provision.

The most important agreement between the three layers of governments took place in 1987, with the approval of the 'Concerted Plan for the Development of the Basic Provision of Social Services by the Local Authorities' (Plan Concertado para el Desarrollo de Prestaciones Básicas de Servicios Sociales de las Corporaciones Locales). This intergovernmental agreement has resulted in administrative co-operation between central, regional and local governments. The aim is to provide services at the municipal level for information and counselling, social and day care services for the disabled and elderly, refuges for abused women, single mothers, orphans or mistreated minors, sheltered housing for the homeless and services to prevent unemployment and aid labour market reentry.

This network of centres constitutes the basic level of primary provision in Spain, and was supported by all nationalities and regions except the Basque Country. The annual financing of this Plan is met on equitable terms by the three layers of governments. This agreement was the first in a model of intergovernmental relations characteristic of the process of federalisation of politics in Spain. It has had substantial implications for other policy areas (Agranoff, 1993).

During this period the major reform carried out by the central government was the generalisation of means-tested old-age and disability pensions. In 1990, legislation on noncontributory pensions provided means-tested benefits for old-age and disabled citizens and their dependants, outside the social insurance system.

After the 1996 general elections, the centre-right Partido Popular (PP) (Popular Party) secured sufficient parliamentary support for its minority government. This was provided by the Basque Nationalists of PNV (Christian Democrats), the Catalan Nationalists of CiU (Convergència i Unió) (Liberals and Christian Democrats), and the nationalists of the Canary Islands (Coalición Canaria) (wide ideological spectrum).

In the period 1996-2000, and as a result of this wide parliamentary coalition of interests, the attempts to cut social expenditure advocated by neo-liberals within the PP were neutralised. An 'expenditure competition' between the governmental party and its parliamentary allies took place. Further to this, the more centrist members of the PP cabinet managed to gain control in those ministries related to social policy and welfare development, and maintained an attitude of negotiation with the social partners (trade unions and employers' associations). The diálogo social(social dialogue) among government and social partners led to several agreements, and was maintained with the objective of preserving the paz social('social peace').

The PP renewed its mandate in the 2000 General Election with an absolute majority of parliamentary seats. The newly formed Cabinet was more inclined to the political centre and declared its commitment to some of the 'Third Way' proposals related to the 'new economy', and to continue the practices of pact building and politics by consent. This latter approach has been an important feature of political conduct in democratic Spain since 1975 , and is now succinctly analysed.

\section{European convergence and the 'Toledo Pact' on social protection}

In 1986 the country joined the European Economic Community. Spain has become an important political partner in the process of further Europeanisation. Since its accession to the EEC/EU the country has followed a path of growing convergence in economic policy output along the lines of some other European Continental countries. Similarly the government has pursued neo-liberal responses to economic pressure and globalisation. Nevertheless, trade union pressure for more welfare spending brought about neocorporatist practices. This course of action, in response to neo-liberalism, reinforced the 
mode of consensual politics inaugurated in the period of transition to democracy, which has maintained negotiation as the cornerstone of welfare development in Spain.

The Social and Economic Agreement (AES, Acuerdo Económico y Social) was signed in 1984, and extended until 1986, by the government, employers' associations and the trade union UGT (CCOO declined to support the pact). Some of the predictions included in the Agreement were later realised: inflation came down in 1984 from 12 to eight per cent. However, unemployment increased and the employees' income share of the national total also diminished.

The confrontation between government and trade unions characterised the second term of the Socialists in power (1986-1989). This period was one of greater governmental concern for social policy and expenditure. Percentage coverage of the unemployed increased up to nearly 50 per cent of the total. A general improvement of retirement pensions was also implemented, as well as the public universalisation of basic education (primary and secondary). These measures completed what some authors have labelled the 'social transition' of Spanish democracy (Estefanía and Serrano, 1987). The trade unions began to give priority to social policy in their programmes of action.

In the aftermath of the 1992 financial crisis of the European Monetary System and its knock-on effects on the Spanish economy, the trade unions revised all attempts at economic pacts with both government and employers. The year 1993 witnessed a deep economic crisis with a high level of unemployment, hardly any job creation and an acute ageing of the working population. The following year the main parliamentary political parties (PSOE, PP, IU and CiU) worked out a crucial inter-party pact on social security which was signed in the city of Toledo at the beginning of 1995 . The Toledo Pact was ratified by the Spanish Parliament on April 6, 1995, and was the origin of subsequent reforms of the system of social protection (Cabanillas Bermúdez, 1997).

The Agreement, whose main points eventually passed into legislation, aimed principally at: reinforcing the contributory nature of the Spanish system of social security; raising social expenditure to the EU average, ensuring that the finances of the scheme were stable and extending universal programmes. The major reforms were a clear division between contributory social insurance, funded by both employers and employees, and universal non-contributory benefits, paid for through general taxation, provision for benefit uprating and procedures for review of the system. Contribution finance was to be fully in place by 2000 , and contributions would be simplified, related more closely to salaries and increased annually in line with the expansion of the system. There would be two general regimes for paid labour and self-employed people: advantageous 'special regimes;' would be brought into line with these. A reserve fund (to be reviewed in 2000) would be established from the annual surplus of the contributory system. Voluntary early retirement would be discouraged by reductions in pension entitlement, except in cases of industrial re-structuring or after expiry of entitlement to unemployment assistance benefits. Disability pensions would be brought within the general scheme. Means-tested supplements financed from general taxation would be paid to families whose contributory pensions did not reach a minimum level, the cost to be re-assessed after four years.

Pensions would be up-rated in line with price increases, taking the finances of the scheme into account. Voluntary and complementary private schemes have been encouraged through tax incentives for occupational provision. Pension calculations were to be based on a ,minimum contribution period of two years from 1997, raised to 15 by 2001 . The rate applied in the calculation of pensions for the first 15 years of contributions was 50 per cent, rising to 80 per cent and 100 per cent for 20 and 25 years. Orphan pensions ages were raised and minimum benefits for widows under the age of 60 were increased.

A Permanent Committee with representatives of the Government and the Trade Unions (UGT and CCOO) was established to monitor the implementation of the reforms. In order to maintain the climate of consensus achieved with the Toledo Pact, the Permanent 
Committee would present initiatives and proposals to the Parliamentary Commission responsible for social protection.

\section{Institutional framework and policy responses}

The Spanish 1978 Constitution was adopted by general consensus of the major political parties and approved by popular referendum [4]. The text reflects many of the tensions and political dilemmas that existed in Spain at the time, soon after the ending of a dictatorship of nearly forty years. However, it also reflects a widespread desire to reach political agreement among all the political parties involved in the process of negotiation.

Spain is a constitutional monarchy which guarantees autonomy to each of the layers in its system of government. In line with the plural internal composition of Spain, which includes three 'historical nationalities' and fourteen regions [5], the 1978 Constitution established an open model of decentralisation which paved the way for the establishment of a federalising Estado de las Autonomías (State of Autonomies).

\section{Universalisation and targeting}

Debates on universality and selectivity in welfare services and transfers have traditionally been related to issues of equity and redistribution. Spain characteristically combines universal and targeted services and has constructed a medium-sized system of social protection, compared with other EU countries (Moreno and Sarasa, 1992; Moreno 2000a). The Spanish welfare state is fundamental to both social reproduction and political legitimisation. Since its integration in the European Community (1986), Spain has followed a pattern of welfare convergence on three levels. Firstly, universalisation of social entitlements (education, health, pensions). Secondly, convergence in social expenditure patterns to the European median. Thirdly, diversification in the provision of social services by private and 'third sector' organisations. In addition, regional home rule can be regarded as the most distinctive factor affecting welfare development in Spain. The decentralisation process embodied in the 1978 Spanish Constitution has permeated all major areas related to both institutional framework and policy-making (see section below).

During the 1980s and 1990s, Spain confronted a period of constant increases in public expenditure at a relatively higher level than in most European countries. This was the result of providing the basis for new and costly social programmes, namely universal coverage in education, public health and the generalisation of pensions. Growth of Spain's public spending has been designed to bring economic rationalisation in line with the rest of the EU countries.

The move to a universal educational system has meant that the entire age group from four to 15 years old has access to nursery, primary, and secondary schooling. About 12 per cent of public education spending goes to concerted private schools. These schools, together with non-concerted private education, covered 31 per cent of the total student population in 1990 (38.6, pre-school; 34.5, elementary; 28.7, middle; and 8.1, university). In 1992, relatively and absolutely, more women than men were in education in the 16 to 29 year old age group. Among the 16-19 year olds, 63 per cent of women were receiving formal education as against 53 per cent of men. Among 20-24 year-olds, the gender gap was more than 8 per cent (EPA, 1993).

The 1986 General Health Act set up a National Health Service, which guaranteed access to health care for all Spaniards and all foreign citizens resident in Spain. Coverage, already high in 1980 (83.1 per cent of all citizens and residents), was almost total by 1991 (99.8 per cent). (Almeda and Sarasa, 1996; Guillén, 2000).

Three quarters of the financing of Spanish health is public. Of the remaining one-quarter, 
85 per cent are direct payments by individuals (mostly for private care and medicines). These figures have remained stable during the 1980-93 period. The most significant variation of this period is the shift of the financing of public expenditure from contributions to taxation. In 1980, as much as 82 per cent of the spending on health was met by social contributions, whereas in 1993 the corresponding figure was 20 per cent. This dramatic change is in line with the assumption that universalisation of the public health service should be related to a system of general financing by taxation on the basis of a more equitable philosophy.

Public expenditure on health during the period 1980-93 rose at a mere 0.5 per cent a year, indicating that universalisation of coverage has not been matched by an equivalent improvement in standards of care. About 8 per cent of the population was covered by private health insurance (Freire, 1993). Some occupational schemes remain for groups in the well-protected core of the workforce.

Powers in the area of health provision have been decentralised to the seventeen Comunidades Autónomas. Some regions of these have implemented policies for the provision of services of a 'quasi-market' nature (Catalonia, Valencia) and have since faced problems in financing of their respective public health systems. Discussion of the adaptation of expenditure to socio-demographic changes has stressed the rationalisation of health consumption, particularly of medicine, and especially for older people. Longer timeseries are needed to evaluate properly the effects of these reforms on hospital management, financial restraint and the improvement of both efficiency and equality on health care.

The case of pensions and its implications for welfare financing is analysed below, but first we examine the most important factor affecting developments and reforms in the Spanish welfare state: the process of decentralisation of power.

\section{Decentralisation and federalisation}

In Spain there has been a growth of institutional 'stateness', or state penetration of the welfare sphere (Flora, 1986/87; Kuhnle, 1997). However, this should not be interpreted in Jacobin terms, by which central administration and government are concepts synonymous to that of the state. In referring to 'stateness' we take into account all state institutions, i.e. central, regional and local. In fact, the Comunidades Autónomas (Autonomous Communities) have taken of leading role in the development of programmes of social assistance and social services. Due to the growing importance of the regional and local levels in the provision of welfare programmes, this is an area of increasing relevance for social policy researchers (Alber, 1995; Moreno and Arriba, 1999).

The construction of the Estado de las Autonomias in Spain had to follow a 'top-down' process of decentralisation. This way of doing things is just one of the options available in the development of federal-like systems. The result at the beginning of the 21 st century is not much more than a series of practices of a federal nature involving a series of politically concurrent units (Moreno, 2000b). The decentralisation process embodied in the 1978 Spanish Constitution has undergone a long period of consolidation. The degree of autonomy for the Spanish nationalities and regions is considerable. This is illustrated by the development of the distribution of public expenditure in Spain's three-tier system of government (Table 1).

Table 1: The Territorial Distribution of Public Spending in Spain (\%)

\begin{tabular}{|l|l|l|l|l|l|l|l|}
\hline & $1981^{1}$ & 1984 & 1987 & 1990 & 1992 & 1997 & $\begin{array}{l}1999 \\
\text { (est.) }\end{array}$ \\
\hline & & & & & & &
\end{tabular}




\begin{tabular}{|l|c|c|c|c|c|c|c|} 
CENTRAL & 87.3 & 75.6 & 72.6 & 66.2 & 63.0 & 59.5 & 54 \\
\hline REGIONAL & 3.0 & 12.2 & 14.6 & 20.5 & 23.2 & 26.9 & 33 \\
\hline LOCAL & 9.7 & 12.1 & 12.8 & 13.3 & 13.8 & 13.6 & 13 \\
\hline
\end{tabular}

${ }^{1}$ Beginning of the process of devolution

Source: Spanish Ministry of Public Administrations (MAP, 1997)

The 1978 Constitution set in train the institutionalisation of the social services in Spain. According to the Spanish Carta Magna, social assistance is a regional power in the 'exclusive competence' of the 17 Autonomous Communities (art. 148,1.20). Powers concerning the basic legislation and the economic regime of the social security system remain within the domain of the central government. However, the Comunidades Autónomas (Autonomous Communities) can exercise executive powers in the running of contributory programmes which can be decentralised to them (art. 149; 1.17). The constitutional provisions neither define nor regulate both realms of social assistance and social services. All powers and responsibilities which are not listed as the 'exclusive competence' of central government can be claimed and exercised by the Autonomous Communities (art 149.3).

As a consequence of the flexibility of the constitutional provisions, all Comunidades Autónomas claimed in their Statutes of Autonomy (regional constitutional laws) a large number of services and functions concerning social assistance, social services, community development, social promotion and welfare policies in general. The only services which remained outside the control of the mesogovernments were those of INSERSO. However executive powers for running practically all INSERSO services were also transferred to the Comunidades Autónomas during the 1990s. [6]

During the period 1982-1993, the Autonomous Communities took the legislative initiative in their regional parliaments, and established regional systems of social services. In these pieces of legislation there were no references to social assistance as such. The implicit assumption was that social assistance was an 'exclusive' power of the Autonomous Communities, alongside social services. The main concern of the mesogovernments in this period was to claim as many powers from the central administration as a flexible interpretation of the 1978 Constitution would allow. The Comunidades Autónomas have made extensive use of their constitutional prerogative for purposes of institutional legitimisation.

A common basis for the legislation adopted by the regional parliaments to develop an integrated network of social services was the principle of decentralisation. According to this local governments would carry out the bulk of service provision, but the powers of legislation, planning, and co-ordination with the private and altruistic sectors would rest upon regional executives and legislatures.

All regional laws envisaged the social services as an integrated public system, open to all citizens without discrimination. Regional legislation on welfare provision was founded on the principles of universal and equal access. Traditional public welfare was to be 'updated' to avoid stigma. All things considered, the aim was one of modernisation of the social services in line with other experiences of welfare provision in Western Europe. Such aspirations were in tune with the aim of rationalising the provision of new social services.

On establishing the public systems of social services, the idea of the welfare 'mix' was also embraced enthusiastically by most Spanish mesogovernments. Non-profit organisations, in particular, were incorporated in the general provision of social services, and many of them were subsidised by the regional public bodies.

The implementation of regional systems of social services in Spain did not proceed without 
some friction with central government. In 1986 a decision of the Constitutional Court (146/1986) established that, despite the 'exclusive' powers of the Autonomous

Communities in this field, the central government could also develop programmes of social assistance guaranteeing equal treatment for all Comunidades Autónomas.

As a consequence of the process initiated in 1978, social assistance and social services are often treated as synonymous. Institutional fragmentation continues to be a defining trait of the Spanish welfare state, although the collaboration of the three layers of government may be seen as a decisive factor in the rationalisation of welfare provision. The process of reform, however, is far from being over.

The approval of regional acts and the development of the Plan Concertado have been carried out on universalistic grounds. Access is, therefore, available for all citizens. Nevertheless, some programmes and benefits, for example, those concerning minimum income guarantees for non-contributory and disability pensioners, are targeted on the leastfavoured as social assistance. As a consequence, both social service culture and the approach of the social workers balances both universalism and selectivity (Serrano and Arriba, 1998).

The principle of decentralisation advanced in regional legislation has concentrated on the transfer of powers from central to meso levels. In fact, a tendency to re-centralise the policy-making process towards the intermediate layer of government (the Comunidades Autónomas) to the detriment of the municipal locus of policy-making is evident.

Important political decisions regarding the IMIs (ingresos mínimos de inserción, programmes of minimum income of insertion) and the organisation and planning of the services developed according to the Plan Concertado, have reflected a higher degree of political dynamism by the Comunidades Autónomas. They have also underlined the subsidiary role played by local councils dependent to a great extent on regional financial sources and political concerns. These have been articulated not only by nationalist and regionalist parties, but also by the increasingly important regional and federated branches of the main Spanish political formations (PP, PSOE, and IU). Internal processes of power accommodation within the parties have therefore contributed to the internalisation of the shift towards federal politics and policy-making. Only the big cities (namely, Madrid and Barcelona) have been able to challenge mesogovernment as main protagonist in the development of social services.

\section{Regional programmes of minimum income}

The considerable expansion of both social services and social assistance programmes has resulted in a de iure segmentation between the contributory (social insurance system for labour market 'insiders') and social assistance areas of welfare provision (for those excluded from the formal labour market). However, both domains are intertwined to produce the sum-total of social provision. This has been inspired by the general principle of social citizenship and has thus expanded the grey areas between social insurance and welfare assistance (Moreno and Sarasa, 1993).

The implementation of the public systems of social services by the Spanish mesogovernments has been coupled with the regional development of new social assistance programmes and the executive management of former social security services. This includes the assistance subsidies inherited from the traditional schemes of public beneficence, the management of the non-contributory pensions and the implementation of the IMIs. Contingent and ad hoc benefits may also be granted to needy citizens. The 'safety net' providing the minimum means of sustenance and civic integration to those citizens and families who lack them rests to a great extent upon the network of regional systems of social services. 
The process of policy innovation related to the programmes of minimum income started in September of 1988 with the announcement by the Basque Government of a regional Plan de Lucha contra la Pobreza (plan against poverty). This sparked off a regional mimesis, or 'demonstration effect', on the part of the other 16 Comunidades Autónomas. By the end of 1990, all Spanish mesogovernments were engaged in the implementation of regional programmes of minimum income (Aguilar et al, 1995; Ayala 1997; Serrano and Arriba, 1998; Arriba, 1999).

Some of the were established mainly on the initiative of the regional governments as a result of combined action by both elected politicians and executive officials. In some other cases, the pressure exerted by the opposition parties in the regional parliaments was the main factor behind the elaboration of these programmes. Finally, a third path of policymaking was due to the mobilisation of the regional branches of the main trade unions (CCOO and UGT) as well as some significant NGOs, such as Caritas.

Despite the different actors shaping the policy-making of the ingresos mínimos de inserción, the regional administrations are the main protagonists: prior to approval by the regional parliaments, no explicit popular demand was voiced in any of the territories of the Comunidades Autónomas for implementation of these policies. The constitutional entitlement of the Autonomous Communities to exercise political autonomy underlay the development of the minimum income guarantee. 'Path dependency' was not involved, demonstrating that developed by sub-state communities with a perspective of 'cosmopolitan localism' can be more effective and efficient in social policy innovation (Moreno, 1999).

The regional programmes of minimum income are conditional quasi-universalistic entitlements, combining cash benefits with activation policies and programmes of social integration, mainly employment promotion and vocational training. Families are the units of reference even though individuals can be single beneficiaries; the means-tested threshold is set at a household income of about two-thirds of the minimum wage; there is a residence qualification of from one to 10 years; and the benefit may be extended, provided that beneficiaries have complied with social insertion activities and their needs remain the same.

The central Ministry for Social Affairs showed reluctance to implement the regional minimum income programmes, due to concern about dependency and labour disincentives. Allegations that these new regional policies could affect territorial solidarity throughout Spain were among its criticisms (Ministerio de Asuntos Sociales, 1989). However, the newly-created Ministry had already opted for making the generalisation of non-contributory pensions its main priority, exhausting in this ambitious programme most of its political capital within the central government. The initiative taken by the Comunidades Autónomas left little room for the institutional manoeuvring of the central Ministry, and was based on the constitutional provisions safeguarding regional self-government. The Socialist Government was unlikely to oppose the implementation of the regional minimum income programmes in this context.

Since the beginning of the process, the debate over the implementation of regional IMIs was unsophisticated (Aliena, 1991). The 'simplicity' of the arguments used by the Basque policy-makers illustrate the point. The IMIs were intended to reduce social marginalisation and discourage labour passivity. Their development was supported by EU recommendations and other European experiences, such as the French Revenu Minimum d'Insertion. There was also a high degree of inter-party consensus and support from various Basque civil institutions.

Spanish mesogovernments have benefited in terms of political legitimation as a consequence of the implementation of the IMls. A clear message of policy innovation and political aggiornamento underlined their commitment to pursue the 'closure' of the system 
of social protection in Spain. The development was facilitated by the fact that they could afford such a highly targeted programme.

Regional governments followed a process of imitation in the implementation of minimum income programmes similar to that for social services legislation. Concerns about regional inequalities were not seriously considered. In fact, the effect of imitation by the different regions has arguably been to equalise the institutional output of the Spanish mesogovernments, at least in terms of social policy innovation. This has resulted in the establishment of a differentiated arena of policy provision vis-à-vis the central government. At the horizontal level the Comunidades Autónomas have followed patterns of mobilisation rooted in a self-perceived 'comparative grievance': no region wants to be left behind. These perceptions have interacted in a conflictual manner with the prerogatives claimed by the Spanish 'historical nationalities': Basque Country, Catalonia and Galicia, who are particularly interested in maintaining a high degree of independence. The combination of these processes has resulted in a de facto policy equalisation and in an incentive for policy innovation in those Spanish regions which have been traditionally lagging behind the 'modernised' ones.

Indeed, policy outcomes have resulted in some visible differences in benefit-levels and, above all, the nature of the 'insertion' programmes. Three groups of IMIs can be identified: workfare, where claimers must work for benefit, schemes linking the subsidy to labour market re-entry and discretionary social assistance benefits (Laparra and Aguilar, 1997). The impact of these innovative minimum income programmes has had an important effect in the debate about the completion of a 'safety net' in Spain. The Ministry of Labour and Social Affairs estimates that there were 211,221 beneficiaries in the whole of Spain (including dependent family members) by 1996, or around half of one per cent of the Spanish population.

\section{Reforms and future scenarios}

As a member of the Mediterranean family of nations, Spain shares with Greece, Italy and Portugal similarities in historical background, value-systems, and institutional characteristics. All four countries had past experiences of authoritarian and dictatorial rule (for longer periods in the case of Portugal and Spain), and have suffered from economic and industrial 'delays' in the processes of modernisation (except for early-industrialised areas in Italy and Spain). Religion has traditionally had a structuring role in all four countries, but the role of the Church as main organiser of social protection has diminished. This seems to correspond with a higher degree of secularisation in the social practices of Southern Europe. The impact of Europeanisation and globalisation has brought about, respectively, increasing incentives to economic convergence with Northern and Central Europe (Economic and Monetary Union) and world-trade pressures to restrict social programmes. In broad terms, similar social-demographic trends, macro-economic constraints and pattern of public policy can be observed in all four South European countries (Giner, 1986, Morlino, 1998; Castles, 1998).

As concerns the cultural and normative dimension of welfare development in Southern Europe there is a self-perception of differentiated needs and lifestyles (intra-familial pooling of resources, home ownership, and heterogeneity of social reproduction). Also noticeable is a compelling household solidarity and a pre-eminent role for family inclusion and life-cycle redistribution (gift mechanisms, processes of age emancipation, proliferation of family companies and jobs). Cultural choices and practices have structured their civil societies in a characteristic mode resulting in heterogeneity of social reproduction, and particularistic practices in various kinds and degrees (social networking, patronage, clientelism, and group predation).

In institutional terms, there are fragmented systems of income guarantees and wide inter- 
generation disparities in cash benefits (for example, over-protection of the elderly in Greece and Italy)[7]. The principle of status maintenance characteristic of the contributory systems in Continental Europe links cash benefits to work position and the benefits are thus to be financed by both employers and employees. There is a preference for subsidiarity and an emphasis on the role of intermediary structures, but state organisations also play a significant role in the production and provision of social services.

Both the Mediterranean welfare mix and the gender/family/work nexus are adaptable and complementary. Analysis of politico-institutional development shows that the pivotal role of the family in social protection cannot be over-emphasised (Naldini, 1999). In Southern Europe the welfare state is to a large extent the Mediterranean welfare family. Intra-familial transfers are both material and through services: the involvement of women in care of the elderly and children is crucial. However, the increasing participation of female workers in the labour force coupled with changes in the patterns of family formation and expansion raises major questions as to whether the system can survive in its current form.

Also characteristic of Southern European labour markets is an apparent cleavage between 'insiders' (the well-protected core workforce), 'peripheral' (marginal) workers and 'outsiders' (precarious, 'left-outs', and 'junk' labourers). There are fragmented systems of income guarantees, and the informal 'tax-free' economies in Southern Europe are large. [8] This produces an uneven distribution of financial burdens across the various occupational groups.

In Spain labour policies are of the foremost importance since the unemployment rate is the highest in the European Union. This section focuses particularly on unemployment, as well as on pensions and the financing of social protection. All three areas are crucial to the future of welfare development.

\section{Unemployment}

According to the annual household survey, unemployment stood at 15.5 per cent or 2.5 million in September 1999, a sharp fall from 22.3 per cent only three years before. The active working population had also grown to approximately 16.5 million, about 41 per cent of the population. It is unclear whether the number registered as unemployed by the governmental job agencies of INEM (Instituto Nacional de Empleo) reflects the situation more accurately. INEM classifies as registered unemployed all those citizens who have filed a job application at any of its agencies and who legally qualify as unemployed: those in work, disabled people and students under the age of 25 are excluded. In order to be eligible for unemployment and social assistance benefits citizens must register. 9.5 per cent of the active working population was registered in September 1999.

Given the high rate of unemployment in Spain, some observers are puzzled by the stable social situation in the country, particularly for younger people: unemployment rates stand at about 40 per cent, for men and 45 per cent for women aged 20-24 years. The lack of social tension may be explained by the relatively high public spending on unemployment benefits (4.8 per cent of the GDP in 1993, the highest percentage among EU-12 countries) and the support of family and household networks of micro-solidarity.

The Acuerdos sobre Estabilidad en el Empleo y Negociación Colectiva (Agreements on Employment Stability and Collective Bargaining) were negotiated between the main Employers' Associations (CEOE and CEPYME) and Trade Unions (CCOO and UGT), and signed on April 1997. Subsequently, the PP Government initiated the legislative implementation of the 'Agreements' with a Law-Decree, which was ratified by 94 per cent of Spanish MPs at the Congress of Deputies on June 6, 1997.

These labour reforms have had an ambivalent impact on job creation and employment stability in Spain. Employment growth has been steady since the implementation of such 
measures. By December 1999 two million stable jobs had been created according to the provisions set by the Acuerdos on 1997 - 70 per cent of all jobs created during the period. However, a third of these were temporary as against an EU average of 11 per cent. Simply to maintain the current proportion of temporary to permanent jobs, two permanent jobs must be created for every temporary job in the years to come.

\section{Pensions}

With the implementation of the Non-contributory Pensions Act, in 1990, means-tested benefits for both old age (over 65 years) and disabled citizens (over 65 per cent of disability) were established. By the late 1990s, there were nearly 8 million pensioners in Spain, of whom nearly 700,000 were non-contributory and around 200,000 were covered by the regional programmes of minimum income. The social security system ended the year with a surplus equivalent to 0.2 per cent of GDP in 1999, which enabled the government to establish, for the first time, a reserve fund. The pay-as-you-go pension system is expected to face a serious imbalance between workers and pensioners from 2005 onwards.

Spain's population is nearly 40 million and the annual growth rate has been a mere 0.2 per cent since the beginning of the 1980s. The main reason is the decline in fertility rates, which fell from 3.0 per cent in 1965 to 2.8 per cent in 1970, 2.1 per cent in 1980 (below that required to ensure inter-generational replacement) and 1.07 in 1999 (the lowest in Europe). Projections for the year 2020 estimate that around 19 per cent of the total population of Spain will be over 65 years of age (European Commission, 1998).

Following the Toledo Pact, the Acuerdo para la Consolidación y Racionalización del Sistema de la Seguridad Social was signed between the Government and the two main Trade Unions (UGT and CCOO) on October 9, 1996. Subsequently the Law on the Consolidation and Rationalisation of the System of the social security was passed on July $15,1997$. This legislation is designed to facilitate control of the expected increase in contributory pension spending. However, in 1998, 90,000 more pensioners joined than left the system (Chuliá, 2000). This figure is indicative of a trend towards a chronic social security deficit unless the growth in the creation of employment is maintained in the near future.

Political pressure on central government to raise minimum pensions mounted in 1999 . Some regional executives participated actively in the demands and, in an early political decision, the Junta de Andalucía decided unilaterally to increase the rates for noncontributory pensioners and to meet the costs out of its own regional resources. The discussion generalised and paved the way to a new agreement between the PP Government and the trade unions. Around three million of non-contributory, survivors', invalidity and minimum-income contributory pensioners benefited from the reform. The average increase of 5.4 per cent compared with the 2 per cent rise for other contributory pensioners.

\section{Welfare financing}

During 1980-93, all Southern European countries increased their social expenditure at a higher rate than the EU-12 average of 3.5 per cent (Table 2). According to Eurostat, social spending in Spain had already reached 24.0 per cent of the GDP by 1993, which compares with the EU-12 average of 27.8 per cent. Data aggregated by welfare regimes shows that previous disparities in social spending fell between 1980 and 1995 (Table 3). The difference between Continental and Mediterranean countries had been reduced by five per cent points. The EU states with the highest real growth rates of benefits per head were the four Southern European countries. Their average percentage increases were above 75 per 
cent, and in the case of Portugal about 140 per cent (Eurostat, 1997b).

Table 2: Social Spending in the EC (EU-12;\% GDP)

\begin{tabular}{|c|c|c|c|c|}
\hline & 1980 & 1985 & 1993 & $\%(1980-93)$ \\
\hline $\begin{array}{l}\text { Belgium } \\
0.4\end{array}$ & 28.0 & 29.3 & 27.6 & - \\
\hline $\begin{array}{l}\text { Denmark } \\
+4.5\end{array}$ & 28.7 & 27.8 & 33.2 & \\
\hline $\begin{array}{l}\text { France } \\
+5.5\end{array}$ & 25.4 & 28.8 & 30.9 & \\
\hline $\begin{array}{l}\text { Germany } \\
+2.2\end{array}$ & 28.8 & 28.4 & 31.0 & \\
\hline $\begin{array}{l}\text { Ireland } \\
+0.8 \\
\end{array}$ & 20.6 & 23.6 & 21.4 & \\
\hline $\begin{array}{l}\text { Luxembourg } \\
1.6\end{array}$ & 26.5 & 23.4 & 24.9 & - \\
\hline $\begin{array}{l}\text { Netherlands } \\
+3.5 \\
\end{array}$ & 30.1 & 31.7 & 33.6 & \\
\hline $\begin{array}{l}\text { United Kingdom } \\
+6.3\end{array}$ & 21.5 & 24.3 & 27.8 & \\
\hline $\begin{array}{l}\text { EU-12 } \\
+3.5 \\
\end{array}$ & 24.3 & 26.0 & 27.8 & \\
\hline $\begin{array}{l}\text { Greece } \\
+6.6 \\
\end{array}$ & 9.7 & 15.4 & 16.3 & \\
\hline $\begin{array}{l}\text { Italy } \\
+6.4\end{array}$ & 19.4 & 22.6 & 25.8 & \\
\hline $\begin{array}{l}\text { Portugal } \\
+6.7 \\
\end{array}$ & 12.8 & 14.1 & 19.5 & \\
\hline $\begin{array}{l}\text { Spain } \\
+5.8 \\
\end{array}$ & 18.2 & 20.0 & 24.0 & \\
\hline
\end{tabular}

Note: Current expenditure at market prices .

Source: Eurostat (1995: 16)

Table 3: Social Expenditure by Welfare Regime (EC-14; \% GDP)

\begin{tabular}{|lcccc|}
\hline & 1980 & 1990 & 1995 & $\%(1980-95)$ \\
\hline $\begin{array}{l}\text { Anglo-Saxon } \\
+6.2\end{array}$ & 21.5 & 24.3 & 27.7 & \\
\hline $\begin{array}{l}\text { Continental } \\
+2.0\end{array}$ & 28.1 & 29.6 & 30.1 \\
\hline $\begin{array}{l}\text { Mediterranean } \\
+7.2\end{array}$ & 15.0 & 18.0 & 22.2 \\
\hline $\begin{array}{l}\text { Nordic } \\
+6.5\end{array}$ & 25.6 & 28.1 & 32.1 \\
\hline
\end{tabular}

Countries: Anglo-Saxon (United Kingdom); Continental (Austria, Belgium, France, Germany, Netherlands); Nordic (Denmark, Finland, Norway, Sweden) and Mediterranean (Greece, Italy, Portugal, Spain). 
Note: Unweighted averages.

Source: Kuhnle (2000: Table 1.1).

Welfare transfers in Spain has been traditionally designed to secure 'income maintenance' for those citizens who have made contributions to the social security system during their working life. Employers' (53 per cent) and employees' (17 per cent) contributions meet the greater part of the financing of social protection spending. However, a significant shift has taken place in recent years with a gradual transferring of public money from the national budget to the social security accounts. In the not too distant future, and depending upon the renewal of the Toledo Pact in 2001, the contributory social security system will be entirely financed through employers' and employees' contributions. General taxation will then be responsible only for the cost of the non-contributory benefits and services.

\section{Conclusion}

Spain has achieved a very rapid and successful expansion of its welfare system since the period of transition to democracy (1975-1978) and subsequent integration in the EEC/EU (1986). Despite the substantial inequalities inherited from Francoism, the country has maintained sustained economic growth and distributed the benefits more equally. Spain's social structure has moved closer to that of neighbouring countries with a notable expansion of the middle classes. As regards welfare development, Spain has avoided the process of retrenchment that has affected the rest Europe for three main reasons: a higher degree of welfare spending has been possible because the country started at a lower level and because Spain's economic growth has been higher than in the rest of Europe. Secondly, the constitutional decentralisation of powers and subsequent process of federalisation has made available considerable autonomy to expand social policies and services at both regional and local levels. Thirdly, and most important, the political legacy has given extra weight to the achievement of broad political and social consensus through negotiation between representative parties and social actors. It is remarkable that such a high degree of consensus has survived alongside decentralisation.

The consensual approach adopted between the government and the social partners during the 1990s has had important repercussions for the consolidation of the system of social protection in Spain. It remains to be seen whether the consensus, which was renewed in the 'Agreement for the Consolidation and Rationalisation of the Social Security System' of 1997, can be maintained in the future, especially in view of the anticipated pressures from the cost of pensions, the high level of unemployment and the declining birth rate.

After the 2000 General Election, which provided the incoming PP Government with an absolute majority in parliament, the question on whether a further liberalisation of public services will mean the end of a climate of negotiation and agreement with the social partners was raised. Neo-liberal groups within the PP are committed to the streamlining of the welfare state, while more centrist groups endorse the maintenance of the diálogo social (social dialogue) on welfare reform. This latter approach has also been renewed with the election in April 2000 of the new leader of the trade union Comisiones Obreras (CCOO), José María Fidalgo. He has insisted on the continuation of the practice of negotiation with the employers' associations and the government for the implementation of new policies and reforms. These will have to deal with four main areas of reform for the near future:

First, the public nature of social protection was reinforced during the 1990s. A multi-party consensus that social spending should keep pace with GDP growth was achieved. The reduction of previous levels of public debt together with a higher growth-rate than the EU average has allowed Spain to sustain its distinctive via media model of welfare development. A gradual separation of sources of finance is necessary to maintain this achievement. The non-contributory system of social assistance is to based on the principle that the cost of universal benefits should be met by society as a whole and financed 
through general taxation. Contributory benefits are to be wholly financed from employers' and employees' contributions, although alternative complementary sources may be used in the future as national wealth increases (for example, a special charge for all taxpayers analogous to the French CSG).

Secondly, internal solidarity within the public pension system of goes hand in hand with a reinforcement of its contributory nature. There is an observable emphasis on the actuarial principle of income maintenance linking cash benefits to be paid by social security more closely with total contributions made during working life. The automatic re-valuation of minimum pensions and improvement of survivors' benefits is intended to provide a 'safety net', along with the non-contributory minimum income benefits of both national and regional programmes of social welfare. The latter are crucial in targeting social policies for the excluded and less-favoured social groups in a context where the 17 Spanish Comunidades Autónomas have full and 'exclusive' powers in the area of concerning social assistance.

Thirdly, social protection in Spain continues to rely heavily on the family as producer and distributor of welfare. The involvement of women in care for both older people and children has been crucial and has been traditionally considered a 'given fact'. However, the increasing participation of female workers in the labour force, coupled with new burdens on family formation and expansion, raise major questions as to whether the Spanish welfare system can survive. More institutional support for women is an essential pre-condition for the reversal of the worrying demographic trends in Spain. At the beginning of 2000, Spain's fertility rate was the lowest in Europe (1.07 per cent), and stood at about half the rate required to maintain population size.

Fourthly, the role of the social partners, and especially of the trade unions and the employers' associations, has become more important. Their co-operation in the negotiation of the 'Agreements on Employment Stability and Collective Bargaining' of 1997 was crucial in steering legislative initiatives and governmental reforms in the consolidation of the welfare state in Spain. The renewal of the Toledo Pact in 2001 is the major challenge in maintaining the diálogo social in the years to come.

In short, the achievements of Spain in expanding its welfare system and in maintaining a social consensus on the direction of reform during the last quarter century are unparalleled in the EU. The crucial question is whether the distinctive Spanish via media in welfare can be sustained in view of pressures from the cost of pensions for a rapidly ageing population, high levels of unemployment and temporary work, the low birth-rate and rapid changes in family patterns and increasing demands from regional authorities.

[1] With the implementation of the 1959 Stabilisation Plan public expenditure was reduced, the Peseta was devalued, and investment controls were relaxed. Foreign holdings of up to $50 \%$ in Spanish companies were permitted. The results of the desarrollismo were impressive, with GDP growing by an annual $7 \%$ between 1960 and 1974.

[2] On February 23, 1981, military officers stormed into Spanish Parliament and kept hostage all members of the Government and of both legislative houses until it became evident that the main bulk of Army commanders did not support the coup.

[3] The ministry was formed by the General Directorate of Social Action, the INSERSO, the Institutes for the Women and the Youth, and the Board for the Education and Care of the Disabled. It also took responsibility of supervising the activities of NGOs, such as the Red Cross, the Blind Persons' Organisation (ONCE, Organización Nacional de Ciegos de España), and other non-profit private charities.

[4] On December 6, 1978, the Spanish Constitution received $87.9 \%$ of 'Yes' votes, $7.8 \%$ of 'No' votes, and $4.3 \%$ of null or blank votes. $32.9 \%$ abstained. 
[5] The Basque Country, Catalonia and Galicia are constitutionally recognised as nacionalidades históricas. The rest of the Comunidades Autónomas are Andalusia, Aragon, Asturias, Balearic Islands, Canary Islands, Cantabria, Castile and Leon, Castile-La Mancha, Extremadura, La Rioja, Madrid, Murcia, Navarre and Valencia. The Spanish North African cities of Ceuta and Melilla have been also chartered local statutes of autonomy.

[6] In 1996, this central governmental agency changed its name (i.e. IMSERSO, Instituto de Migraciones y Servicios Sociales, Institute for Migration and Social Services). It has kept minor executive programmes regarding services for emigrants, as well as some co-ordination functions with EU programmes.

[7] Italy and Greece are well above the EU mean percentage of $62.0 \%$ for the per capita average pension ( $77.6 \%$ and $78.8 \%$ in 1991, respectively). This is not the case of Spain and Portugal $(47.3 \%$ and $42.1 \%$, respectively) with a more balanced inter-generation distribution of resources.

[8] According to a much-criticised memorandum of by the European Commission in March 1998, the 'underground' economy of Spain provided between 10 and 23\% of GDP. The European average varies between 7 and $16 \%$.

\section{References}

Agranoff, R. (1993), 'Las relaciones intergubernamentales y el Estado de las Autonomías', Política y Sociedad 13: 87-105.

Aguilar, M.; Gaviria, M. and Laparra, M. (1995), La caña y el pez. El salario social en las Comunidades Autónomas 1989-1994, Madrid: Fundación Foessa.

Alber, J. (1995), 'A Framework for the Comparative Study of Social Services', Journal of European Social Policy, 5, (2): 131-149.

Aliena, R. (1991) 'RMI, le Gouvernement espagnol à contre-courant' in Revue Française des Affaires Sociales 45: 81-97.

Almeda, E. and Sarasa, S. (1996), 'Growth to Diversity', in V. George and P. Taylor-Gooby (eds.) European Welfare Policy. Squaring the Welfare Circle, pp. 155-176. London: Macmillan.

Arriba, A. (1999), Rentas mínimas de inserción en España: Procesos de implantación y dinámicas sociales. Ph.D. thesis, Universidad Autónoma de Madrid Facultad de Ciencias Económicas y Empresariales.

Ayala, L. (1997), Ánálisis económico de los sistemas de rentas mínimas en España desde una perspectiva comparada. Ph.D. thesis, Universidad Complutense de Madrid, Facultad de Ciencias Económicas y Empresariales.

Beltrán, M. (1992), El régimen jurídico de la acción social pública. Oñati: IVAP.

Cabanillas Bermúdez, J.M. (1997), El Pacto de Toledo. Análisis descriptivo del Sistema Nacional de la Seguridad Social en España. Madrid: Tecnos.

Casado, D.; Aznar López, M.; Casado de Otaola, D.; Gutiérrez Resa, A., and Ramos Feijó, C. (1994), 'Acción social y servicios sociales', FOESSA, V Informe Sociológico sobre la situación en España. Sociedad para todos en el año 2000, pp. 1735-1880. Madrid: Fundación FOESSA

Castles, F. (1998), Comparative Public Policy: Patterns of Post-war Transformation. Northampton, Mass : Edward Elgar.

Chuliá, E. (2000), El Pacto de Toledo y la política de pensiones. ASP Research Paper 33(a)/2000. Madrid: Analistas Socio-Políticos.

CIS (1996), Estudio 2.213, Madrid: Centro de Investigaciones Sociológicas. 
Estefanía, J. and Serrano, R. (1987), 'Diez años de relaciones industriales en España in Zaragoza, A. (ed), Pactos sociales, sindicatos y patronal en España, pp. 17-42. Madrid: Siglo XXI.

Eurostat (1995), Eurostat Yearbook 1995: A Statistical Eye on Europe, 1983-93, Luxembourg: OOPEC.

Eurostat (1997), Eurostat Yearbook '97. A Statistical Eye on Europe 1986-1996. Luxembourg: OOPEC.

Flaquer, LI.; Giner, S. and Moreno, L. (1990), 'La sociedad española en la encrucijada' in Giner, S. (ed), España. Sociedad y Política, pp. 19-74. Madrid: Espasa Calpe.

Flora, P. (1986/87), Growth to Limits. The European Welfare States Since World War II, Berlin: De Gruyter.

Freire, J.M. (1993), 'Cobertura sanitaria y equidad en España', El impacto de las políticas sociales: educación, salud, vivienda, pp 113-138. Madrid: Fundación Argentaria.

Giner, S. (1986), 'Political Economy, Legitimation and the State in Southern Europe, in G. O'Donnell and P. Schmitter (eds.) Transitions from Authoritarian Rule: Prospects for Democracy, Baltimore: John Hopkins University Press.

Guillén, A. (2000), La construcción política del sistema sanitario español: De la postguerra a la democracia. Madrid: Exlibris.

Kuhnle, S. (1997) 'La reconstrucción política de los Estados del Bienestar europeos', in Moreno, L. (ed.) Unión Europea y Estado del Bienestar, pp. 31-65. Madrid: CSIC.

Kuhnle, S. (ed.) (2000), The Survival of the European Welfare State, Routledge, London.

Laparra, M. and Aguilar, M. (1997), 'Social Exclusion and Minimum Income Programs in Spain', in MIRE Comparing Social Welfare Systems in Southern Europe, vol. 3, Florence Conference, pp. 515-535. Paris: Mission Recherche et Expérimentation (MIRE).

MAP (1997), Estudio sobre reparto del gasto público en 1997 entre los distintos niveles de administración. Madrid: Ministerio de Administraciones Públicas.

Ministerio de Asuntos Sociales (1989), Informe sobre diferentes prestaciones sociales en la CEE y España. Mimeo.

Moreno, L. (1999), 'Local and Global: Mesogovernments and Territorial identities', Nationalism and Ethnic Politics 5 (3/4): 61-75.

Moreno, L. (2000) 'The Spanish development of Southern European welfare', in S.Kuhnle (ed.) Survival of the European Welfare State, pp 146-65, Routledge, London.

Moreno, L. (2001), The Federalisation of Spain. London: Frank Cass.

Moreno, L. and Arriba, A. (1999), Welfare and Decentralisation in Spain. Working Paper EUF No. 99/8. Florence: European University Institute.

Moreno, L. and Sarasa, S. (1992) The Spanish 'Via Media' to the Development of the Welfare State. Working Paper 92-13, Madrid: IESA-CSIC.

Moreno, L. and Sarasa, S. (1993), 'Génesis y desarrollo del Estado del Bienestar en España', Revista Internacional de Sociología 6: 27-69.

Morlino, L. (1998), Democracy between Consolidation and Crisis: Parties, Groups and Citizens in Southern Europe. Oxford: Oxford University Press.

Naldini, M. (1999), Evolution of Social Policy and the Institutional Definition of Family Models. The Italian and Spanish cases in Historical and Comparative Perspective. Ph.D thesis. Florence: European university Institute. 
Rodríguez-Cabrero, G. (1989), "Política social en España: realidades y tendencias" in Muñoz, R. (ed.), Crisis y futuro del Estado del Bienestar, pp. 183-204. Madrid: Alianza.

Sarasa, S. (1993), El servicio de lo social. Madrid: Ministerio de Asuntos Sociales.

Serrano, A. and Arriba, A. (1998), ¿Pobres o excluidos? El Programa del Ingreso Madrileño de Integración en perspectiva comparada. Madrid: Fundación Argentaria-Ministerio de Trabajo y Asuntos SocialesEditorial Visor.

Published in P. Taylor-Gooby (ed.), Welfare states under pressure, pp. 100-122, London: Sage, 2001.

$4[\mathrm{CSIC}]$ [UPC] [Working Papers] 